\title{
Effect of Propionate Supplement on the Fatty Acid Composition of Adipose Tissue in Sheep Fed with High Concentrate Ration
}

\author{
Toshiyoshi TAKAHASH and Takeo KAYABA \\ Department of Bioproduction, Faculty of Agriculture. \\ Yamagata University Tsuruoka-shi 997
}

(Received July 23, 1992)

\begin{abstract}
Key words : propionate, high concentrate ration, adipose tissue, fatty acid composition, sheep
\end{abstract}

The present authors reported perviously that propionate supplementation in sheep improved feed utilization when feeding a high concentrate ration ${ }^{11}$, and that supplementation was not effective for a high roughage ration ${ }^{9}$. Furthermore, the desaturation of fatty acids in adipose tissue was observed at the ratios of $2: 8^{9)}$ and $5: 5^{5)}$ of the concentrate to roughage in growing / fattening sheep, and at the ratios of $6: 4^{72}$ and $5: 5^{2)}$ in beef cattle given propionate supplements, respectively. However, desaturation in sheep given a high roughage ration $^{9)}$ was weaker compared with those given equal ratios of concentrate and roughage ${ }^{5)}$. In the case of the hamster, which is similar to ruminant animals in nutritional characteristics such as the mechanism of fatty acid synthesis in adipose tissue ${ }^{3)}$, its feed utilization improved and the desaturation of its whole body was promoted as a result of high concentrate and high roughage feedings supplemented with propionate $^{10)}$. It is thought to be of profound significance that a feeding method for meat production from ruminant animals would simultaneously achieve the improvement of feed utilization and bring about the desaturation of fatty acids in adipose tissue.

This study was carried out to examine the fatty acid composition of adipose tissue via the biopsy method in sheep which were fed a high concentrate ration supplemented with propionate in the previous growing/fattening trial $^{11}$.

\section{Materials and Methods}

Experimental animals and feeding: Eight castrated Suffolk sheep $(53.7 \mathrm{~kg}$ in average body weight) were used. Four sheep constituting the control plot were fed mixed rations of concentrate (commercial formula feed for beef cattle) and roughage (chopped grass hay) in the ratio of $8: 2$ on a dry weight basis. The remaining four, constituting the experimental plot, were fed with the same mixed rations supplemented with calcium propionate. Calcium propionate was supplemented $1 \mathrm{~mol}$ per

濃厚飼料多給メン羊におけるプロピオン酸塩添加が体脂肪の脂肪酸組成に及ぼす影響：高橋敏能・亘場猛夫（山形 大学農学部, 鶴岡市 997) 
$790 \mathrm{~g}$ as dry matter in the ration. The amount of TDN was given at $37.5 \mathrm{~g} /$ body weight $\mathrm{t}^{0.75} /$ day for both plots, and was corrected every four weeks based on body weight. At $60.8 \mathrm{~kg}$ in body weight, for example, $94 \mathrm{~g}$ of propionate was supplemented to the ration of $940 \mathrm{~g}$ concentrate and $240 \mathrm{~g}$ roughage. All rations were sufficiently mixed with suitable water and fed at $9: 30$ once a day. Water was given freely throughout the experiment. Sheep were housed in metabolic cages at a room temperature of $18-22^{\circ} \mathrm{C}$ for seven months ; i.e. for one month as preliminary term and for six months as the plenary term.

On the final day of the feeding trial, the sheep were anesthetized with sodium pentobarbital, and abdominal subcutaneous adipose tissues were sampled from the right side by means of a surgical operation. Lipid extracted from adipose tissues by FoLcHs' method ${ }^{11}$ was converted into methylester with $5 \% \mathrm{HCl}$ methanol $(\mathrm{W} / \mathrm{W})$.

The fatty acid compositions in adipose tissue were measured in the same manner as descrived in a previous report ${ }^{5 \text { ? }}$.

The significance of the difference was evaluated via analysis of the variance $F$-test of $\mathrm{SAS}^{4)}$.

\section{Results and Discussions}

Propionate supplements had a tendency to show down the speed of feed intake by sheep, and the changes in feed intake showed twophase patterns during both treatments ${ }^{11}$. A comparison of fatty acid composition in subcutaneous adipose tissue is given in Table 1. There is no difference in the composition (\%) of $\mathrm{C}_{16: 0}$ acid and branched chain plus normal odd number carbon fatty acids between the two feedings. In the propionate feeding, $\mathrm{C}_{18: 0}$ fatty acid was significantly lower and $\mathrm{C}_{18: 1}, \mathrm{C}_{18: 2}$ and $\mathrm{C}_{18: 3}$ fatty acids tended to be higher than in the control feeding. Consequently, propionate supplementation in a high concentrate ration led to the desaturation of fatty acids in the adipose tissue; the composition (\%) of unsaturated fatty acids was 50.0 for propionate feeding to 41.1 for control feeding and the ratios of total unsaturated fatty acids of 18 in carbon number to $C_{18: 0}$ fatty acid were 2.7 to 1.8 , respectively $(\mathrm{P}<0.05)$.

Two mechanisms of desaturation in adipose tissue via propionate supplementation during high concentrate feeding are suggested; i.e. one is a decline of biohydrogenating ability into unsaturated fatty acids of fodder via microorganisms in the rumen with the propionate supplement ${ }^{6)}$ and the other is an increase in dehydrogenation activity from adipose tissue due to the activation of desaturase stimulated by insulin secretion ${ }^{12)}$. In pervious reports ${ }^{8,11)}$, insulin secretion was stimulated more by propionate supplementation during high concentrate feeding than in high roughage feeding. The stimulation of insulin secretion may be due to the rapid feed intake in high concentrate feeding ${ }^{11}$ as compared with high roughage feeding ${ }^{9)}$ and the increase in propionic

Table 1. Fatty acid composition of the subcutaneous adipose tissue

\begin{tabular}{|c|c|c|c|c|c|c|c|c|c|c|c|}
\hline \multirow[b]{2}{*}{ Treatment } & \multicolumn{10}{|c|}{ Fatty acids (weight \%) } & \multirow{2}{*}{$\begin{array}{l}\text { USFA } \\
\text { SFA }^{3}\end{array}$} \\
\hline & $C_{1400}$ & $C_{16: 0}$ & $\mathrm{C}_{16: 1}$ & $C_{17: 0}$ & $C_{18: 0}$ & $C_{i 8: 1}$ & $C_{18: 2}$ & $\mathrm{C}_{18: 3}$ & $\begin{array}{c}\mathrm{BC}+\mathrm{NONC} \\
\mathrm{FA}^{(1)}\end{array}$ & USFA $^{27}$ & \\
\hline Control & 2.6 & 21.1 & 1.5 & 2.2 & $22.6^{\mathrm{A}()}$ & 32.8 & 4.0 & 2.8 & 12.7 & $41.1^{\mathrm{B}}$ & $1.8^{\mathrm{B}}$ \\
\hline+ Propionate & 1.6 & 20.1 & 1.5 & 2.8 & $17.7^{\mathrm{B}}$ & 38.3 & 6.3 & 3.8 & 9.4 & $50.0^{\mathrm{A}}$ & $2.7^{\mathrm{A}}$ \\
\hline
\end{tabular}

\footnotetext{
1); Branched chain + normal odd number carbon fatty acids.

${ }^{2)}$; Unsaturated fatty acids.

3); $\mathrm{C}_{18: 1}+\mathrm{C}_{18: 2}+\mathrm{C}_{18: 3} / \mathrm{C}_{18: 0 .}$

4); Figures without common superscripts significantly differ at 0.05 probability level.
} 
acids both in rumen liquor and in blood plasma $^{8,11)}$. Therefore, the desaturation of adipose tissue from $\mathrm{C}_{18: 0}$ to $\mathrm{C}_{18: 1}, \mathrm{C}_{18: 2}$ and $\mathrm{C}_{18: 3}$ fatty acids might be stimulated by increased dehydrogenation activity of the adipose tissue and by the decline in biohydrogenating ability in the rumen.

From the results described above, it is obvious that propionate supplementation in a high concentrate ration is very significant for meat production from sheep because feed utilization was improved ${ }^{11}$ and the desaturation of fatty acids in adipose tissue was promoted, concurrently.

\section{Acknowledgment}

The authors are grateful to $\mathrm{Mr}$. Hideki Mомог for his helpful assistance during this experiment.

\section{References}

1) Folch, J., M. LeEs and G.H. SLOANStanley, A simple method for the isolation and purification of total lipids from animal tissues. J. Biol. Chem., 226 : 497509. 1957.

2) Itabashi, H., Effect of VFA supplement and protozoa removal on fatty acid composition of adipose tissue in beef cattle. (Translated title by present authors.) Proceedings of Japanese Society for Animal Nutrition and Metabolism, 23: 85-95. 1979.

3) Murai, M., Nutritional and physiological characteristics in hamster. (Translated title by present authors.) Experimental Herbivora, $11: 50-62.1986$.

4) SAS Institute Inc., SAS User's Guide. 5th ed. 433-506. Cary, NC, U.S.A. 1985.

5) Takahashi, T. and S. OOta, The effects of the ratio of concentrate and roughage and supplements VFA salts on fattening and fatty acid composition in adipose tissue of sheep, Jpn. J. Zootech. Sci., 56: 711-719. 1986.

6) TAKahashi, T., Effect of various types of feeding on the ability of biohydrogenation and VFA production in sheep rumen in Vitro. Bull. Yamagata Univ., Agr. Sci., $10: 253-264.1987$.

7) Takahashi, T., T. Kayaba, S. Dota and H. Yamaguchi, Studies on effective utilization of self-sufficing roughages in fattening of Holstein steers. Final Reports for Research Grants for Meat and Meat Products, 7 : 112-125. 1988.

8) Takahashi, $T$., T. Imamura and $T$. KaYABA, Effect of dietary propionate on insulin response with feeding of different concentrate-roughage ratios in sheep. Asian-Australasian J. Anim. Sci., 2: 249250. 1989.

9) Takahashi, T., T. Imamura, K. Horiguchi, T. KaYaba and H. Sano, Effect of propionate-supplemented roughage on stimulation of insulin secretion, feed utilization and fatty acid composition in adipose tissue in sheep. Bull. Yamagata Univ., Agr. Sci., 11 : 445-462. 1992.

10) TAKahashi, T. and T. Kayaba, Effect of dietary VFA on feed utilization and fatty acid deposition of whole body in growing hamster and rat. J. Japan Grassl. Sci., $38: 234-237.1992$.

11) Takahashi, T., H. Momor., T. Kayaba and H. Sano, Effect of feeding of high concentrate ration supplemented propionate on the feed utilization and the blood characteristics in sheep. Jpn. J. Sheep Sci., 29 : 35-40. 1992.

12) Yамамото, K., Metabolism in hormone and lipid. 1st ed. (Translated title by present authors.) 79-81. Kyoritsuzensho. Tokyo. 1982. 